[CONTRIBUTION FROM THE JOHN HARRISON LABORA TORY OF CHEMISTRY, No. 46.$]$

\title{
THE PERSULPHATES OF RUBIDIUM, CESIUM, AND THALLIUM.
}

By Arnott R. Foster and Fidgar F. SMith.

Received Angust 2, 189 s.

SINCE Hugh Marshall prepared a number of persulphates $\int$ these salts have attracted considerable attention both from a theoretical and practical standpoint. As the potassium and ammonium salts are generally those which are made and with which experiments are conducted we concluded to attempt the production of the persulphates of rubidium and cesium. We employed a "divided cell," using for the purpose that one recommended by Nernst which is so convenient that it should become a valuable adjunct in class experimentation.

RUBIDIUM PERSULPHATE,

To obtain this salt a solution consisting of two-thirds part sulphuric acid (I.35 sp.gr.) and one-third part of a saturated rubidium sulphate solution was electrolyzed, the cell being surrounded by a freezing-mixture of sodium chloride and ice.

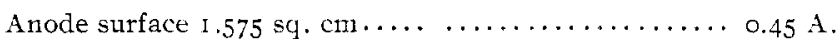

Voltage $. . . \ldots \ldots \ldots \ldots \ldots \ldots \ldots \ldots \ldots \ldots, 8$

A white precipitate began to separate at the anode after twenty minutes. The deposition at first was very slow, but later it became more rapid. The deposit was freed by filtration from the adherent liquid by washing it with cold water. Its aqueous solution oxidized a ferrous salt and liberated iodine from potassium iodide. The salt crystallized from water in acicular, vitreous forms.

Analysis.

The available oxygen was determined with ferrous ammonium sulphate and potassium permanganate. The oxidation proceeded slowly so that heat was applied to the solution of the persulphate and iron ammonium sulphate in an atmosphere of carbon dioxide. The oxygen liberated by ignition from a given quantity of the salt in an atmosphere of carbon dioxide was collected over caustic potash and measured. 
I. $0.338 \mathrm{I}$ gram of the persulphate on ignition gave 0.2484 gram of rubidium sulphate or 73.47 per cent., instead of $73.5 \mathrm{I}$ per cent., required by theory.

II. 0.2608 gram of the persulphate, acting upon ferrous ammonium sulphate $(2.3633$ grams), showed the presence of 0.0129774 gram of oxygen, equivalent to 4.69 per cent., instead of 4.4 I per cent. (calculated).

III. A second titration of the persulphate was made with 0.2608 gram of the salt and 2.7190 grams of ferrous ammonium sulphate, when 0 .I 884 gram of oxygen was found, equivalent to 4.55 per cent., instead of $4.4 \mathrm{I}$ per cent.

IV. Oxygen by volume. 0.3254 gram of the persulphate gave II.7 cc. of oxygen at $27^{\circ}$ and $773 \mathrm{~mm}$. pressure, or 0.01486784 gram equivalent to $4.5^{6}$ per cent., instead of $4.4 \mathrm{I}$ per cent.

These results, therefore, conclusively demonstrate that rubidium persulphate, $\mathrm{K}_{2} \mathrm{Rb}_{2} \mathrm{O}_{8}$ or $\mathrm{KRbO}_{4}$, really does exist.

$\mathrm{V}$. Meyer's method was used in determining the solubility of this salt. Ioo parts of water dissolved (I) 3.32 parts and (2) 3.49 parts of the salt at $22.5^{\circ} \mathrm{C}$.

\section{CESIUM PERSULPHATE.}

It was formed by electrolyzing a chilled mixture of two-thirds part sulphuric acid (sp. gr. I.35), and one-third part of a saturated cesium sulphate solution in the same manner as with rubidium sulphate.

Anode surface 1.57 sq. $\mathrm{cm} \ldots \ldots \ldots \ldots \ldots \ldots \ldots, 0.3^{2}$ ampere.

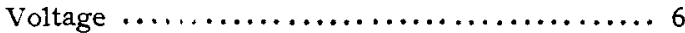

A white deposit began to form at the anode in fifteen minutes. It separated even more rapidly than in the case of the rubidium persulphate. It was filtered out, washed thoroughly and analyzed. Its aqueous solution showed oxidizing properties, liberating iodine from potassium iodide and converting ferrous into ferric salts. The persulphate also crystallizes in colorless needles. Its analysis proved less satisfactory than that of the corresponding rubidium salt. It was difficult to obtain constant weight by ignition. The volume of oxygen was generally too high, although the results obtained by titration were entirely satisfactory. 


\section{Analysis.}

I. 0.4348 gram of the salt and 2.0797 grams of ferrous ammonium sulphate, showed the presence of 0.0143 gram of oxygen, equivalent to $3.3 \mathrm{I}$ per cent., instead of 3.50 per cent.

II. $0.2612 \mathrm{gram}$ of the persulphate and $2 . \mathrm{II}_{32}$ grams of ferrous ammonium sulphate showed 0.008439 gram of oxygen, equal to 3.59 per cent., instead of $3.5^{\circ}$ per cent., by theory.

Upon determining the solubility of the persulphate by $\mathrm{V}$. Meyer's method, it was found that roo parts of water dissolved 8.7 I parts of the salt at $23^{\circ} \mathrm{C}$; again, roo parts dissolved 8.98 parts of the persulphate at the same temperature

THALLIUM PERSULPHATE.

As thallium in some respects resembles the alkali metals, it occurred to us that perhaps it might also yield a persulphate. Accordingly, a saturated solution of its sulphate, treated with sulphuric acid (sp. gr. I.70), as in the preceding examples, was chilled and electrolyzed.

Anode surface $1.57 \mathrm{sq} . \mathrm{cm} \ldots \ldots \ldots \ldots \ldots \ldots \ldots \ldots \ldots, 0.45 \mathrm{~A}$.

Voltage................................ I4

At the expiration of an hour a white precipitate began to separate at the anode. It proved to be very soluble in water, and difficulty was experienced in getting it pure. In fact it decomposed so rapidly in the air that the analysis of it was abandoned. Its aqueous solution rapidly oxidized ferrous salts and set iodine free from potassium iodide. More than this we cannot offer for this salt which is undoubtedly produced in the oxidation of thallous sulphate.

\section{THE CHROMIC ACID TEST FOR COCAINE.}

BY GEORGE I, SCHAEFER,

Received July 7 , 1899 .

INCE the publication of my proposed new test for cocaine, $\checkmark$ several articles have appeared in criticism thereof, which call for some reply.

P. W. Squire' states that the test "produces a turbidity in solutions of the best commercial samples of cocaine hydrochlorate." Further than this he does not go, but in a note appended

1 "The New Test for Cocaine," Chemist and Druggist, Aptil 22. 